\title{
Bicuspidon aff. hatzegiensis (Squamata: Scincomorpha: Teiidae) from the Upper Cretaceous Csehbánya Formation (Hungary, Bakony Mts)
}

\author{
László Makádi \\ Department of Paleontology, Eötvös Loránd University, Budapest
}

The recently discovered Upper Cretaceous (Santonian) Iharkút terrestrial vertebrate locality has yielded several vertebrate taxa since its discovery. Scincomorphan lizards are also represented in this fauna by several jaw fragments. The most abundant of these is represented by seven dentary fragments and an indeterminate jaw fragment with characteristic teeth. The hypertrophied splenial, the heterodont dentition, the cementum deposition at the bases of the teeth and the large subcircular resorption pits assign this type to the family Teiidae. The dentition composes of conical, monocuspid teeth in the mesial region and transversely widened bicuspid teeth in the distal region. This morphology is well known in members of the subfamily Polyglyphanodontinae. Based on their dental morphology the Iharkút finds can be easily assigned to the genus Bicuspidon. This genus is known from two species, B. numerosus Nydam et Cifelli, 2002 from the Albian-Cenomanian of Utah (North America) and $B$. hatzegiensis Folie et Codrea, 2005 from the Maastrichtian of the Haţeg Basin (Transylvania, East Europe). The Hungarian specimens differ from Bicuspidon numerosus while the latter has bicuspid teeth in the distal part of the tooth row, in contrast with the Hungarian species which has two monocuspid teeth in the distal region, one equal to the size of the preceding teeth, and one less than half the size of the former one. The presence of monocuspid teeth at the end of the tooth row resembles $B$. hatzegiensis, but while the very end of the tooth row of the latter is not known, it is not possible to determine if B. hatzegiensis also has two monocuspid teeth distally. Thus it is not impossible that the Hungarian specimens represent a new species but presently the lack of the needed information allows its determination only as Bicuspidon aff. hatzegiensis.

Keywords: lizards, Polyglyphanodontinae, Bicuspidon, Upper Cretaceous, Csehbánya Formation, Bakony Mts, Hungary 
e-mail: iharkutia@yahoo.com

\section{Introduction}

Terrestrial lizards are poorly known from the Upper Cretaceous of Europe. Southern France (Champ Garimond, Cruzy, Villeveyrac Basin, Cassagnau, Vitrolles-Couperigne, La Neuve), northern Spain (Laño, Chera) and the localities of the Haţeg Basin (Transylvania, western Romania) produced remains but all these localities are from the Campanian or Maastrichtian (Buffetaut et al. 1996, Buffetaut et al. 1999, Grigorescu et al. 1999, Rage 1999, Codrea et al. 2002, Company 2004, Folie and Codrea 2005). Most of the remains are jaw fragments or isolated teeth, and usually do not allow exact taxonomic determination.

Now the Late Cretaceous (Santonian) terrestrial vertebrate locality at Iharkút (western Hungary) has yielded three taxa of scincomorphan lizards beside remains of fishes, amphibians, turtles, crocodylians, dinosaurs, birds and pterosaurs (Makádi et al. in press, Ösi and Rabi in press). The significance of these Iharkút scincomorphan specimens is that their state of preservation is much better than that of the most European Upper Cretaceous lizard finds, thus allowing more precise taxonomic determinations as well as paleobiological, paleobiogeographical and evolutionary implications.

\section{Geological setting}

The locality is situated near the village Iharkút, in the Bakony Mts, western Hungary (Fig. 1). At the fossil site the open-pit mining of the bauxite exposured the Csehbánya Formation, which contains the bone-yielding layers. The Csehbánya Formation is the overburden of the Nagytárkány Bauxite Formation and the Triassic Main Dolomite Formation. It is composed of floodplain and channel deposits built up of variegated clay, siltstone with grey and brown sand, sand and sandstone beds (Haas and Jocha-Edelényi 1979, Mindszenty et al. 1984, Knauer and Siegl-Farkas 1992, Jocha-Edelényi and Császár 1997). At the locality the Csehbánya Formation is covered by the Eocene Iharkút Conglomerate, at some places by the Oligo-Miocene Csatka Formation, and at some places only by Quaternary deposits.

A characteristic of the Csehbánya Formation (Fig. 1) is its cyclicity. The basis of the cycle is a sandy, pebbletic base-breccia containing clay clasts, carbonized plant remains and a 
mixture of isolated bones of different animals („bonebed”) (Tuba et al. 2006). Its thickness varies between 15-40 centimeters, most vertebrate remains were found in this type of layers. It contains the bones concentrated in large amounts, enriched in „pockets”. Remains of different individuals of various taxa are embedded in it, which are almost exclusively isolated bones. The deposition of these base-breccias is in connection with mud flows initiated by sudden floods, which collected the remains of animals and plants and deposited them in backwaters, forming these rocks rich in organic material and fossils (Mindszenty A. pers. comm.). This base-breccia is covered by more or less cemented sand and sandstone and above that, greyish-brownish siltstone. This siltstone also contains large amounts of carbonized plant remains and sometimes bones, mostly turtle shell fragments, moreover some of the partial Hungarosaurus tormai Ösi, 2005 skeletons were also found in it. Upwards it becomes gradually finer until the thick green clay closing the cycle. Sometimes the cyclothemes end with soilified floodplain facies, which may also contain some bones.

Based on palynological examinations the Csehbánya Formation was dated as Santonian (Knauer and Siegl-Farkas 1992), and recently this dating was supported also by magnetostratigraphic measurements (Mártonné 2005).

\section{Material and methods}

For the present paper seven more or less fragmentary dentaries and lower jaw fragments and an indeterminate jaw fragment were available (Fig. 2). The bones are black of pyrite and organic material (Tuba et al. 2006), and extremely fragile, but relatively well preserved. The most complete remains were found during the field works while examining through the bonebed by hand. Because screen-washing usually destroys the fragile bones held together by the matrix, only the indeterminate jaw fragment was found by screen-washing from the bonebed type layer. The extremely fragile specimens were fixed in the field with super-glue (cyanoacrylate). Preparation was made in the laboratory using an Opton Stemi SR stereomicroscope. Matrix was removed with sharp needles and local use of $10 \%$ acetic acid. Matrix accidentally hardened by the glue in the field was softened up using acetone. Continuous fixing and hardening with super-glue was necessary during the preparation. Photographs were taken using the Amray 1830I scanning electron microscope of the Department of Petrology and Geochemistry, Eötvös Loránd University at an accelerating voltage of 20kV. Specimens 
were coated with carbon for this purposes, after taking the photos specimens were carefully cleaned of carbon with ethanol.

The specimens are the property of the Hungarian Natural History Museum (MTM).

\section{Systematic paleontology}

The systematics of Estes (1983) was used with respect for later phylogenies. For the anatomical descriptions the orientation terminology proposed by Smith and Dodson (2003) was used, and for the morphology of Bicuspidon teeth the terminology of Kosma (2004) was applied with some modifications.

Ordo Squamata Oppel, 1811

Infraordo Scincomorpha Camp, 1923

Familia Teiidae Gray, 1827

Subfamilia Polyglyphanodontinae Estes, 1983

Genus Bicuspidon Nydam et Cifelli, 2002

Type species: Bicuspidon numerosus Nydam et Cifelli, 2002

Bicuspidon aff. hatzegiensis Folie et Codrea, 2005

\section{Description and comparisons}

At the locality the most abundant scincomorphan is represented by seven lower jaw and an indeterminate jaw fragments.

The lower jaw fragments are between 6 and $11 \mathrm{~mm}$ long and bear one to ten teeth. The indeterminate jaw fragment is one $\mathrm{mm}$ long with a single characteristic tooth. Its state of preservation does not allow to identify if it was an upper or a lower jaw fragment.

Based on their dental features and morphological similarities these eight specimens are considered as belonging to the same taxon. 
The dentaries are massively built especially in the case of the larger individuals (Fig. 3, 4) similarly to Bicuspidon numerosus and B. hatzegiensis, their ventral edge is convex in labial view like that of B. numerosus (Nydam and Cifelli 2002, Folie and Codrea 2005). The labial surface of the dentaries shows no signs of ornamentation. Small alveolar foramina are observable on the labial side of the dentaries. In lingual view the subdental shelf is tall like in B. numerosus (Nydam and Cifelli 2002), with a deep subdental gutter. One specimen preserves a part of the hypertrophied splenial (a synapomorphy of Teiidae, Estes et al. 1988).

The robust teeth have subpleurodont mode of attachment with cementum depositions at their bases as a teiid synapomorphy (Estes et al. 1988). Their cross-section is circular to slightly widened in transverse direction similarly to both Bicuspidon species (Nydam and Cifelli 2002, Folie and Codrea 2005). The degree of widening of the teeth in transverse direction does not reach the extent observed in Polyglyphanodon and Paraglyphanodon (Estes 1983, Nydam 1999, Nydam and Cifelli 2005). Approximately half of their height is projected beyond the labial wall of the bone, slightly less than in B. numerosus and B. hatzegiensis. The teeth are closely packed and most of them have large subcircular resorption pits at their bases common in teiids (Estes et al. 1988). Some of the specimens have empty tooth positions and some have significantly worn tooth crowns.

The dentition is heterodont, commonly in Teiidae (Estes 1983). The anterior teeth (Fig. 5) are conical, circular in cross section, and have a single cusp on the crowns like in $B$. numerosus (Nydam and Cifelli 2002). In distal direction the teeth become gradually larger except the most posterior one. A second, smaller lingual cusp becomes more prominent on the tooth crowns in the mid-part of the tooth row. The teeth in the middle and middle-distal part of the tooth row (Fig. 6) are moderately widened transversely, and have a typical tooth crown characteristic in polyglyphanodontines like Bicuspidon, Dicothodon, Polyglyphanodon and Paraglyphanodon (Nydam and Cifelli 2002, Folie and Codrea 2005, Nydam 1999, Estes 1983, Nydam and Cifelli 2005). This means the presence of a large labial cusp (cuspis labialis) and a slightly smaller lingual cusp (cuspis lingualis), which are linked together by a labiolingual transverse ridge or blade (carina intercuspidalis), dividing the tip of the crown to a mesial and a distal facet (antrum intercristatum anterior and posterior). In the case of the Iharkút specimens the carina intercuspidalis is V-shaped like in Bicuspidon and in Dicothodon (Nydam and Cifelli 2002, Folie and Codrea 2005, Nydam and Cifelli 2005). Internal striae are not present within these facets like in B. hatzegiensis and in contrast with some teeth of $B$. numerosus (Nydam and Cifelli 2002, Folie and Codrea 2005). From the tip of the cuspis labialis weak blunt carinae run down lingually, one on the mesial (crista mesialis) and one on 
the distal side (crista distalis). From the tip of the cuspis lingualis two similar carinae run down labially (crista lingualis anterior and posterior). The crista mesialis and the crista distalis run lingually to meet each other on the lingual side and wrap around the cuspis lingualis as a faint cingulum like in Bicuspidon (Fig. 6). They do not contact the ventrolabially directed crista lingualis anterior and posterior of the cuspis lingualis. This is the state observed in Bicuspidon, contrasting with the morphology exhibited by Dicothodon, Polyglyphanodon and Paraglyphanodon, where the crista mesialis meets the crista lingualis anterior and the crista distalis meets the crista lingualis posterior, forming a mesial and a distal accessory blade (Nydam and Cifelli 2002, Folie and Codrea 2005, Nydam 1999, Estes 1983, Nydam and Cifelli 2005). On the lingual side of the smaller lingual cusp some vertical striae can be observed like in B. hatzegiensis (Folie and Codrea 2005).

The posterior teeth have circular cross-section and tend to lose the smaller lingual cusp. On some Iharkút Bicuspidon specimens (MTM V.01.24., MTM V.01.27. and MTM 2006.111.1.) the distal part of the tooth row exhibits monocuspid teeth (Fig. 4, 7), thus differing from $B$. numerosus in which all the distal teeth are bicuspid, with a small but distinct cuspis lingualis gently separated from the cuspis labialis (Nydam and Cifelli 2002). On the Iharkút specimens the last but one tooth is the largest regarding both width and height. The last tooth (preserved on MTM V.01.27. and on MTM 2006.111.1.) is significantly smaller, about one third of the size of the preceding tooth (Fig. 8, 9).

\section{Discussion}

The morphology of the dentaries unambiguously assigns the remains to the Teiidae. The hypertrophied splenial, the cementum deposition at the bases of the teeth, the heterodont dentition and the large subcircular resorption pits are teiid synapomorphies as mentioned by Estes (1983) and Estes et al. (1988). This was later confirmed by several authors (Rage 1999, Nydam and Cifelli 2002, Kosma 2004). Moreover, the teeth both in the Iharkút dentaries and in the indeterminate jaw fragment allow generic determination even by themselves. Within teiids transversely expanded bicuspid teeth occur in members of the subfamily Polyglyphanodontinae (sensu Estes 1983). The subfamily is known from the AlbianCenomanian boundary till the end of the Cretaceous from North America, Europe and Asia. Its members are taxa like Polyglyphanodon, Paraglyphanodon, Dicothodon, Peneteius (and its synonym Manangyasaurus) and Bicuspidon numerosus from North America, Bicuspidon 
hatzegiensis (and the Iharkút Bicuspidon) from Europe, Macrocephalosaurus, Darchansaurus, Erdenetosaurus, Adamisaurus and Cherminsaurus from Mongolia (Estes 1983, Nydam 1999, Alifanov 2000, Keqin and Norell 2000, Nydam et al. 2002, Nydam and Cifelli 2002, Folie and Codrea 2005).

The Hungarian specimens can be easily distinguished from Peneteius because the latter has conical monocuspid teeth mesially and mammal-like distal teeth with accessorial cusps and complex morphology (Nydam et al. 2002). The Asian taxa have also radically different tooth morphology, with polycuspate, leaf-like (Macrocephalosaurus), or obliquely widened polycuspate (Cherminsaurus), or bulbous (Adamisaurus) tooth crowns in the distal part of the tooth row (Estes 1983, Nydam 1999, Alifanov 2000, Nydam and Cifelli 2002). Dicothodon has well-developed mesial and distal accessorial blades on the tooth crown, bordering deep antrum intercristatum anterior and posterior (Nydam 1999, Nydam 2002). Polyglyphanodon and Paraglyphanodon (the latter considered as a possible juvenile form and thus a synonym of Polyglyphanodon by some authors, Estes 1983, Nydam and Cifelli 2002) have more transversely widened teeth and horizontal or U-shaped carina intercuspidalis instead of the Vshaped blades of Bicuspidon and the Hungarian finds. Polyglyphanodon and Paraglyphanodon also have the accessory blades like Dicothodon, though not so acute and bordering not so deep associated basins, whereas Bicuspidon and the Iharkút specimens lack accessory blades (Estes 1983, Nydam 1999, Nydam and Cifelli 2002, Folie and Codrea 2005). Another difference between Bicuspidon and Polyglyphanodon is that the latter has suppressed tooth replacement thus lacking the characteristic deep subcircular resorption pits (Nydam 1999, Nydam and Cifelli 2002, Folie and Codrea 2005). As noted, the Iharkút specimens exhibit these characteristic resorption pits similarly to Bicuspidon and most Teiidae.

These morphological features easily allow the generic determination of the here studied Iharkút specimens as Bicuspidon. The specific determination evokes more problems. $B$. hatzegiensis was distinguished from B. numerosus by Folie and Codrea (2005; pp. 64-65.) on the basis of three main differences: 1: „Differs from $B$. numerosus in teeth bearing well-developed labial and lingual striae”, 2: ,and by having the posteriormost tooth only slightly smaller than the other ones, bearing a conical crown devoid of sharp and V-shaped transverse ridge”, 3: „Moreover, except for the fragment PSMUBBV367, the teeth are around half the size of those of Bicuspidon numerosus.".

From these three characters, the first and the third are of considerably doubtful taxonomic value. The striae on the enamel of the tooth crowns can be easily missing due to abrasive wear. As noted by Nydam and Cifelli (2002) striated and smooth teeth can be present together 
even on the same specimen. Tooth size has a taxonomic value compared to the size of the jaw, but the photos of B. hatzegiensis (Folie and Codrea 2005; p. 65., fig. 4.) show that the dentary fragments themselves are also approximately half the size of those of B. numerosus, thus not excluding the possibility of an ontogenetic, not a taxonomic difference.

Still, the second character listed by Folie and Codrea (2005) allows distinguishment between B. numerosus and B. hatzegiensis, as the presence of a monocuspid tooth in the distal part of the tooth row of $B$. hatzegiensis, and probably the transversely slightly more widened teeth of B. hatzegiensis (Nydam and Cifelli 2002; p. 278., fig. 2., Folie and Codrea 2005; p. 65., fig. 4.) enable specific distinguishments.

The presence of monocuspid distal teeth in the case of the Iharkút specimens allows differentiation from B. numerosus. The small last monocuspid tooth present on two Iharkút Bicuspidon specimens causes difference also from B. hatzegiensis, but while the very distal part of the tooth row of the latter is not known, it cannot be excluded that B. hatzegiensis also had a smaller last monocuspid tooth behind the known large one. Thus it is possible that the Iharkút Bicuspidon specimens belong to B. hatzegiensis, but it is also probable, that they represent a new species. As a result, the Iharkút Bicuspidon specimens are determined as Bicuspidon affinis hatzegiensis, until more information is not available.

Those Iharkút Bicuspidon specimens which do not have the distal teeth preserved are not determinable specifically, but following the rule of parsimony, they are regarded as belonging to the same species until no evidence of the opposite is discovered.

\section{Conclusions}

From the Upper Cretaceous (Santonian) Iharkút locality the presence of the genus Bicuspidon was demonstrated. The specimens can be distinguished from B. numerosus, and can be determined as $B$. aff. hatzegiensis.

As the most abundant scincomorphan lizard from the Iharkút locality, Bicuspidon aff. hatzegiensis is the oldest teiid in Europe, and the second reported occurrance of the genus in Europe.

The extraordinary state of preservation compared to other European Upper Cretaceous lizard remains allows paleobiological studies such as microwear analyses in the future. The abundancy of the species at the locality shows the greater role of teiids in the Iharkút fauna. 
The North American relationship of this Hungarian teiid supports previous hypotheses which suggest North American rather than Asian influence on European Late Cretaceous faunas.

\section{Acknowledgements}

The author wishes to thank Attila Ösi, Ágnes Görög, Márton Venczel, András Galácz, Andrea Mindszenty, Mihály Gasparik and Zoltán Szentesi for their helps, advises and useful suggestions. The referees are acknowledged for their useful comments and advises The help of Péter Pekker and Károly Bóka in taking SEM photos is gratefully acknowledged. The author is thankful to the Bakony Bauxite Mining Ltd. and to the Geovolán Ltd. for their help in field works. This work was supported by the Hungarian Scientific Research Fund (OTKA) project No. T-38045, the National Geographic Society, the Jurassic Foundation, the Pro Renovanda Cultura Hungariae Foundation, the MOL and several other institutions and private companies.

\section{References}

Alifanov, V.R. 2000: The fossil record of Cretaceous lizards from Mongolia. - In: Benton, M.J., M.A. Shiskin, D.M. Unwin, E.N. Kurochkin (eds): The age of dinosaurs in Russia and Mongolia, pp. 368-389. Cambridge University Press, Cambridge

Buffetaut, E., G. Costa, J. Le Loeuff, M. Martin, J.-C. Rage, X. Valentin, H. Tong 1996: An Early Campanian vertebrate fauna from the Villeveyrac Basin (Hérault, southern France). - Neues Jahrbuch für Geologie und Paläontologie Monatshefte, 1996/H1, pp. $1-16$.

Buffetaut, E., J. Le Loeuff, H. Tong, S. Duffaud, L. Cavin, G. Garcia, D. Ward 1999: Un nouveau gisement de vertébrés du Crétacé supérieur á Cruzy (Hérault, Sud de la France). - Comptes Rendus de la Académie des Sciences, Sciences de la Terre, 328, pp. 203-208.

Codrea, V., T. Smith, P. Dica, A. Folie, G. Garcia, P. Godefroit, J. van Itterbeeck 2002: Dinosaur egg nests, mammals, and other vertebrates from a new Maastrichtian site of the Haţeg Basin (Romania). - Comptes Rendus Palevol, 1, pp. 173-180. 
Company, J.R. 2004: Vertebrados continentales del Cretácico Superior (CampanienseMaastrichtiense) de Valencia. - PhD dissertation, pp. 1-410. Valencia

Estes, R. 1983. Sauria terrestria, Amphisbaenia. - Encyclopedia of paleoherpetology, Part 10A: 1-249. Gustav Fischer Verlag, Stuttgart and New York

Estes, R., K. de Queiroz, J. Gauthier 1988: Phylogenetic relationships within Squamata. - In: Estes, R., G. Pregill (eds.): Phylogenetic relationships of the lizard families - Essays commemorating Charles L. Camp, pp. 119-281. Stanford University Press, Stanford

Folie, A., V. Codrea 2005. New lissamphibians and squamates from the Maastrichtian of Haţeg Basin, Romania. - Acta Palaeontologica Polonica, 50/1, pp. 57-71.

Grigorescu, D., M. Venczel, Z. Csiki, R. Limberea 1999. New latest Cretaceous microvertebrate fossil assemblages from the Haţeg Basin (Romania). - Geologie en Mijnbouw, 78, pp. 301-314.

Haas J., E. Jocha-Edelényi 1979: A dunántúli-középhegységi felsőkréta üledékciklus ősföldrajzi elemzése. - Annual Report of the Hungarian Geological Institute 1977., pp. $217-223$.

Jocha-Edelényi E., G. Császár 1997: Csehbányai Formáció. - In Császár G. (ed.): Magyarország litosztratigráfiai alapegységei, pp. 83-84. Budapest.

Keqin, G., M.A. Norell 2000: Taxonomic composition and systematics of Late Cretaceous lizard assemblages from Ukhaa Tolgod and adjacent localities, Mongolian Gobi Desert. - Bulletin American Museum of Natural History, 249, pp. 1-118.

Knauer J., Á. Siegl Farkas 1992: Palynostratigraphic position of the Senonian beds overlying the Upper Cretaceous bauxite formations of the Bakony Mts (A bakonyi felsö-kréta bauxitformációk szenon fedőképződményeinek palynosztratigráfiai helyzete.). Annual Report of the Hungarian Geological Institute 1990., pp. 463-471.

Kosma, R. 2004: The dentitions of recent and fossil scincomorphan lizards (Lacertilia, Squamata) - Systematics, Functional Morphology, Paleoecology. - PhD dissertation, pp. 1-187. Hannover

Makádi L., G. Botfalvai, A. Ösi 2006: Egy késő-kréta kontinentális gerinces fauna a Bakonyból I.: halak, kétéltüek, teknősök, gyíkok. - Földtani Közlöny, 136/4, pp. $487-$ 502.

Mártonné Szalai E. 2005: Paleomágneses vizsgálatok Iharkúton. - Manuscript, ELTE Department of Applied and Environmental Geology.

Mindszenty A., J. Knauer, F. Szantner 1984: Az iharkúti bauxit üledékföldtani jellegei és felhalmozódási körülményei. - Földtani Közlöny, 114/1, pp. 19-48. 
Nydam, R.L. 1999: Polyglyphanodontinae (Squamata: Teiidae) from the medial and Late Cretaceous: new taxa from Utah, U.S.A. and Baja California del Norte, Mexico. Vertebrate Paleontology in Utah Miscellaneous Publication, 99/1, pp. 303-317.

Nydam, R.L. 2002: Lizards of the Mussentuchit local fauna (Albian-Cenomanian boundary) and comments on the evolution of the Cretaceous lizard fauna of North America. Journal of Vertebrate Paleontology, 22/3, pp. 645-660.

Nydam, R.L., R.L. Cifelli 2002: A new teiid lizard from the Cedar Mountain Formation (Albian-Cenomanian boundary) of Utah. - Journal of Vertebrate Paleontology 22/2, pp. 276-285.

Nydam, R.L., R.L. Cifelli 2005: New data on the dentition of the scincomorphan lizard Polyglyphanodon sternbergi. - Acta Palaeontologica Polonica, 50/1, pp. 73-78.

Nydam, R.L., J. Gauthier, J.J. Chiment 2002: The mammal-like teeth of the Late-Cretaceous lizard Peneteius aquilonius Estes, 1969 (Squamata, Teiidae). - Journal of Vertebrate Paleontology, 20/3, pp. 628-631.

Ösi A., M. Rabi 2006: Egy késő-kréta kontinentális gerinces fauna a Bakonyból II.: krokodilok, dinoszauruszok, pteroszauruszok és madarak. - Földtani Közlöny 136/4, pp. 503-526.

Rage, J.-C. 1999: Squamates (Reptilia) from the Upper Cretaceous of Laño (Basque Country, Spain). - Estudios del Museo de Ciencias Naturales de Alava, 14 (Número especial 1), pp. 121-133.

Smith, J.B., P. Dodson 2003: A proposal for a standard terminology of anatomical notation and orientation in fossil vertebrate dentitions. - Journal of Vertebrate Paleontology, 23/1, pp. 1-12.

Tuba Gy., P. Kiss, M. Pósfai, A. Mindszenty 2006: Diagenezis-történeti vizsgálatok a bakonyi felső-kréta dinoszaurusz lelőhely csontanyagán. - Földtani Közlöny, 136/1, pp. 1-24. 